\title{
TEKNIK PELASHINGAN MUATAN KONTAINER ON DECK PADA KAPAL MV.ORIENTAL RUBY UNTUK PENANGGULANGAN PERGESERAN MUATAN
}

\author{
Aziz, S ${ }^{\mathrm{a}}$, Andromeda, V.F \\ ${ }^{a}$ Taruna Program Studi Nautika Politeknik Ilmu Pelayaran Semarang. \\ ${ }^{b}$ Dosen Program Studi Nautika Politeknik Ilmu Pelayaran Semarang.
}

\begin{abstract}
ABSTRAK
Proses pelashingan kontainer merupakan salah satu hal penting yang perlu diperhatikan dalam pelaksaanaan bongkar muat. Baik atau buruknya pelashingan muatan merupakan salah satu faktor yang sangat berpengaruh terhadap keamanan muatan, bahkan stabilitas kapal pada saat melaksanakan pelayaran. Penelitian ini bertujuan untuk lebih meningkatkan pengetahuan mengenai cara penggunaan alat-alat lashing sesuai dengan fungsinya masing-masing serta cara pelashingan peti kemas yang lebih baik sesuai dengan prosedur yang benar.

Penelitian ini dilaksanakan di atas kapal MV. Oriental Ruby, yang merupakan salah satu armada kapal milik PT. SPIL. Pelaksanaan penelitian selama dua belas bulan satu hari ini dilaksanakan pada saat penulis melaksanakan Praktek Laut (Prala), sehingga sumber data diperoleh langsung dari tempat penelitian berupa informasi-informasi berdasarkan hasil pengamatan.

Hasil penelitian ini menunjukkan bahwa masih terdapat banyaknya kekurangan yang terjadi dalam proses pelaksaanaan pelashingan muatan, baik dalam hal pengetahuan maupun perlengkapan peralatan. Penulis yakin dengan memberikan gambaran tentang metode pelasingan kontainer tersebut, para anak buah kapal akan memiliki pengetahuan tentang teknik pelashingan muatan dengan meningkatkan keoptimalisasian pelashingan muatan sehingga tidak terjadi pergeseran muatan yang dapat berdamapak buruk terhadap stabilitas kapal, ataupun muatan itu sendiri.
\end{abstract}

\section{Kata Kunci: Teknik Pelashingan, Kualitatif, Stabilitas}

\section{PENDAHULUAN}

Penggunaan peti kemas dalam transportasi muatan umum makin lama makin meningkat pada dekade ini. Dalam dunia pelayaran telah terjadi kemajuan yang cukup pesat dalam sistim pengamanan peti kemas. Tujuan pengamanan antara lain, agar muatan dapat sampai di pelabuhan tujuan dengan aman, cepat dan biaya terjangkau. Muatan akan mengalami kerusakan jika tidak terikat dengan kencang. Lashing dapat digunakan untuk mengencangkan muatan agar muatan itu kencang dan tidak bergeser, terutama muatan di on deck.

Dalam mengurangi kerusakan fisik terhadap peti kemas, penataan muatan di pelabuhan dan tata cara lashing yang sesuai standard sangat diperlukan, karena dapat berpengaruh pada keselamatan kapal dan muatan selama pelayaran. Sesuai dengan bentuk konstruksi kapal untuk pengangkutan, pada kapal jenis container mempunyai lashing untuk muatan yang berbeda dengan kapal-kapal lain pada umumnya.

Keamanan muatan merupakan salah satu hal yang perlu diperhatikan selama muatan berada di atas kapal. Dalam penyusunan muatan container diatas kapal, jika palka (in hold) telah terisi penuh, maka sisa muatan yang belum dimuat di dalam palka dapat dimuat di atas deck, dengan syarat tidak melebihi kapasitas muat dengan memperhitungkan stabilitas kapal. Muatan yang dimuat di atas deck perlu ditangani sesuai prosedurnya. Peranan pengikatan muatan di atas deck yang sesuai prosedur inilah yang menjadi penunjang keselamatan muatan. Perlu diketahui bahwa muatan yang bergeser dapat berakibat buruk pada stabilitas kapal yang dapat mengakibatkan kerugian bagi pihak kapal dan pemilik muatan. Agar supaya muatan tersebut tidak bergeser dari tempatnya selama dalam pelayaran yang mungkin berakibat buruk untuk stabilitas kapal, sehingga perlu adanya pelashingan. Pengikatan muatan sangatlah penting terutama bagi muatan yang berada di atas palka. Pengikatan muatan yang benar akan membuat muatan-muatan tidak bergeser dari tempatnya selama dalam pelayaran baik pada saat menghadapi cuaca buruk, ataupun tidak. Dengan adanya pelashingan muatan container yang sempurna dan memenuhi standar lashing container, diharapkan muatan dapat terjamin keamanannya, akan tetapi pada kenyataannya pengikatan muatan yang sesuai 
standar belum sepenuhnya dilaksanakan dengan baik.

Pelashingan muatan container di kapal MV. Oriental Ruby akan diuraikan berdasarkan pengalaman, pengamatan dan penelitian selama penulis melakukan praktek laut. Adapun dalam setiap proses pelashingan seharusnya dapat memenuhi ketentuan cara lashing peti kemas yang benar, tetapi pada kenyataannya di lapangan, banyak terdapat kekurangan pengetahuan tentang cara pelashingan yang sesuai dengan prosedur dalam keamanan muatan. Misalnya : Pada setiap pemasangan twistlock yang mana dalam aturan penggunaannya harus menggunakan 4 buah lashing dalam setiap susunan peti kemas, tetapi pada kenyataannya di lapangan hanya menggunakan 2 buah twistlock kemudian sering pula ditemukan pemasangan twistlock yang tidak sesuai pada penempatannya, sehingga pada saat pembongkaran muatan membutuhkan pembukaan lockpin secara manual, apabila hal tersebut tidak dilakukan maka container yang berada dibawahnya akan ikut terangkat secara bersamaan. Masalah lain yang sering di temukan ialah pada susunan tier teratas yang semestinya perlu di beri bridgefitting namun pada kenyataannya hal ini sangat jarang di gunakan. Kekurangan pengetahuan prosedur keamanan muatan ini membuat keamanan muatan tidak terjamin seutuhnya selama berada di atas kapal.

Dari latar belakang di atas kita bisa melihat kenyataannya di lapangan banyak terdapat ketidak sesuaian prosedur pengikatan. Dengan berbagai kekurangan tentang pelashingan yang sesuai dengan prosedur ini, maka penulis tertarik untuk mengangkat permasalahan tersebut.

\section{KAJIAN PUSTAKA}

Dalam rangka melakukan pembahasan mengenai teknik pelashingan muatan kontainer on deck pada kapal MV. Oriental Ruby untuk penanggulaangan pergeseran muatan, maka perlu diketahui kajian pustaka yang diambil dari berbagai kepustakaan yang berkaitan dengan pembahasan prosiding ini:

A. Muatan Kapal

Menurut Hananto Soewedo (2016:32) definisi muatan kapal adalah barang berupa bread bulk (barang yang tidak dimasukkan ke dalam petikemas) atau barang yang dimasukkan ke dalam peti kemas (container) milik shipper atau pemilik barang untuk dikapalkan sampai ke pelabuhan tujuan. Berdasarkan pengertian diatas dapat disimpulkan bahwa muatan kontainer adalah segala macam barang milik shipper atau pemilik barang yang dapat dimuat dan diangkut di dalam jenis petikemas secara aman sampai ke pelabuhan tujuan.

B. Pengikatan Muatan/Pelashingan Muatan

Menurut Hananto Soewedo (2016:44) pengikatan (lashing) muatan sangat diperlukan untuk muatan diatas kapal agar muatan tidak dapat bergerak sehingga tidak merusak muatan lain atau mengubah stabilitas kapal. Muatan petikemas diatas deck tier pertama dan kedua, di lashing dengan lashing khusus untuk peti kemas, sedangkan yang diatasnya hanya dikunci dengan alat pengunci (twistlock).Untuk menjadikan muatan tidak bergerak, maka perlu adanya pengikatan atau lashing agar muatan yang telah dipadatkan tersebut tetap kokoh dan menyatu dengan badan kapal. Berikut gambar susunan serta pola pelashingan container di atas palka.

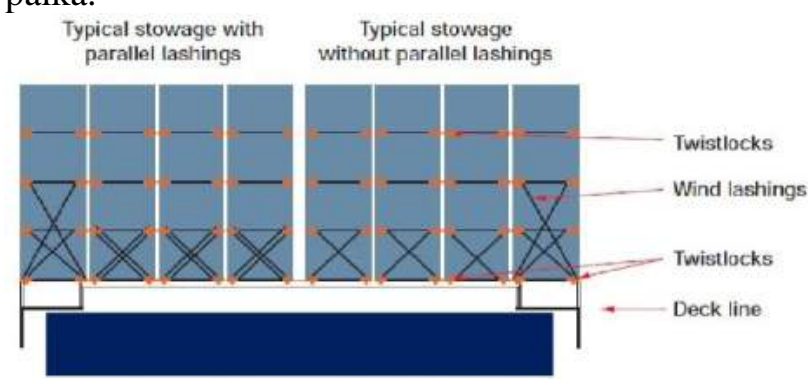

Gambar Pola Pelashingan Kontainer On Deck

Peti kemas di ikat dengan twistlock dan lashind rods. Lashing rods ke dasar tier ke dua. Wind lashing rods dari tier ke 3 ke dasar. Peti kemas tier paling bawah yang dimuat di atas deck harus terikat dengan aman ke struktur kapal untuk memastikan stabilitas dari muatan selama pelayaran. Peti kemas yang dimuat di atas deck diatur dengan kombinasi peti kemas dua puluh kaki dan empat puluh kaki. Perangkat lashing yang pada umumnya digunakan adalah sepatu petikemas (twistlock), lashing rods dan turnbuckle. Menurut Arso Martopo (2001:77) kontainer 40 kaki bisa ditempatkan di atas kontainer $20 \mathrm{kaki} /$ feet, kontainer 20 feet tidak bisa ditempatkan di atas kontainer $40 \mathrm{kaki} / \mathrm{feet}$. Pintu kontainer ditempatkan menghadap buritan kapal.

C. Alat-alat lashing kontainer

Menurut Fakhrurrozi (2016:41) kondisi lashingan muatan diatas kapal harus selalu dilakukan pengecekan dalam interval waktu minimal sekali dalam sehari pada cuaca laut 
baik. Tapi dalam kondisi cuaca buruk interval pengecekan lashingan muatan harus lebih ditingkatkan dengan sering dilakukan dan jika perlu diberikan tambahan lashingan untuk muatan-muatan geladak yang dimungkinkan kekhawatirannya akan bergerak atau bergeser. Dalam Jurnal Saintek Maritime Volume XVI Nomor 2, menurut Mokhammad Abrori (2017:110) alat-alat lashing yang biasa dijumpai diatas kapal antara lain: single bridge base cone, double bridge base cone, double stacking single cone, deck pin atau deck locking pin, pigeon hook, corner casting pin, twistlock, screw bridge fitting, turnbuckle, lashing rod, extention hook, lashing point. uraikan

Berikut ini adalah kerangka pikir yang akan penulis

Teknik PelashinganMuatan Kontainer On Deck Pada Kapal MV.Oriental Ruby Untuk Penanggulangan Pergeseran Muatan

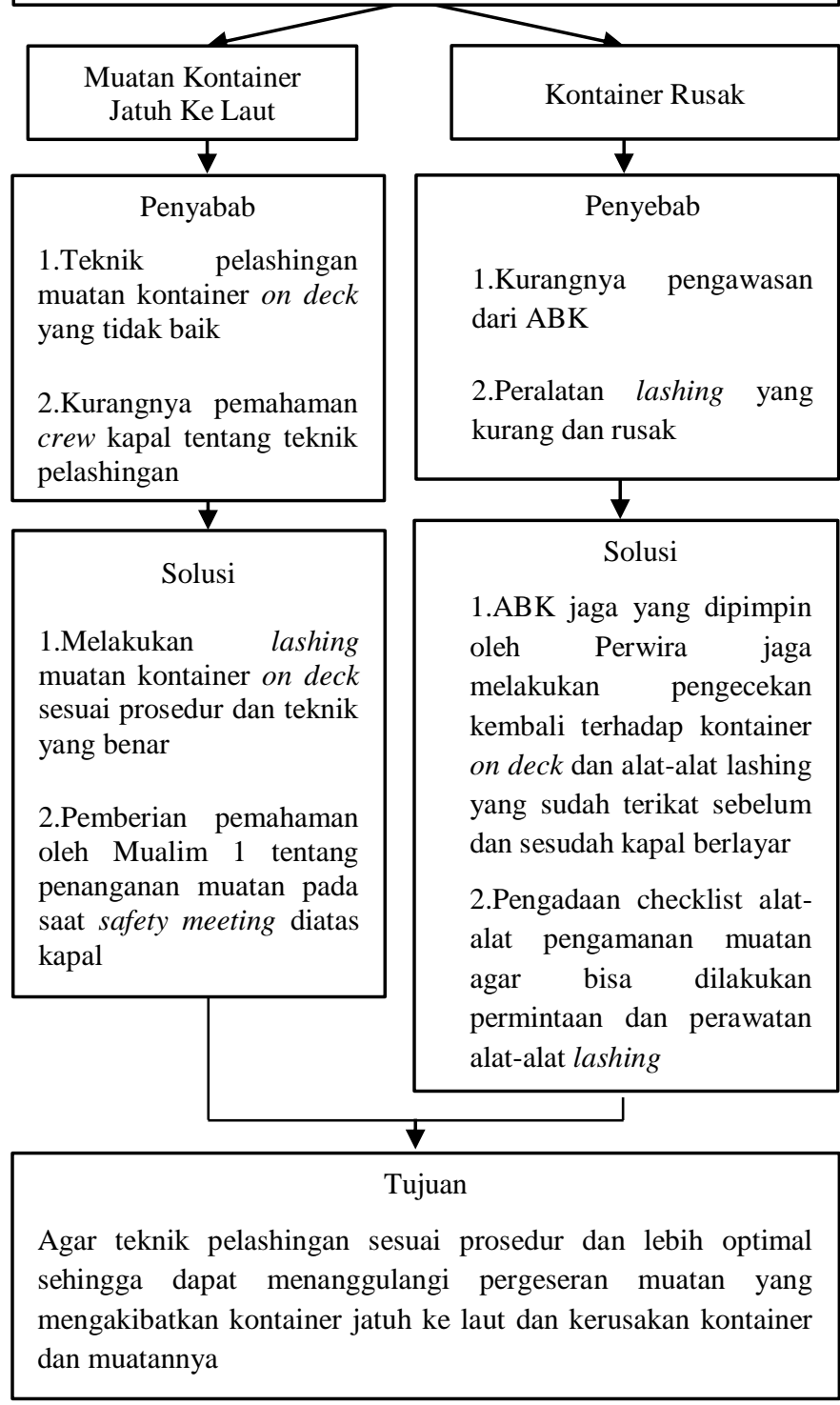

Gambar Kerangka Pikir

\section{METODOLOGI}

Metode penelitian yang digunakan oleh penulis dalam penyampaian masalah adalah metode penelitian kualitatif dengan penyajian data secara deskriptif, untuk menggambarkan dan menguraikan secara diteliti. Menurut I Wayan Suwendra dalam bukunya Metodologi Penelitian Kualitatif (2018:5), "penelitian kualitatif" adalah penelitian yang ingin menangkap makna di balik fenomena (peristiwa, persepsi, sikap, pemikiran, aktifitas, social, dan pemikiran) dalam konteks sosial. Penelitian dilakukan di kapal MV. Oriental Ruby milik PT. Salam Pasifik Indonesia Line (SPIL). Adapun waktu penelitian ini yaitu selama 12 bulan 1 hari dimulai dari tanggal 01 Agustus 2017 sampai dengan 02 Agustus 2018 tepatnya pada saat penulis melaksanakan praktek laut di atas kapal tersebut. Pada penelitian ini penulis akan memberikan berbagai macam data yang bersifat kualitatif, dari berbagai macam sumber data yang penulis pergunakan pada saat penyususan skripsi.

Data Primer Menurut Asep Hermawan dalam bukunya Penelitian Bisnis (2005:168) "data primer" merupakan data yang dikumpulkan secara langsung oleh peneliti untuk menjawab masalah atau tujuan penelitian dengan menggunakan metode pengumpulan data berupa survey maupun observasi. Data primer ini akan digunakan penulis sebagai bukti untuk merumuskan masalah yang terjadi dan menentukan metode-metode yang akan digunakan serta untuk menjelaskan secara rinci masalahmasalah yang terjadi ditempat penulis melakukan penelitian dan penyelesaiannya. Data yang diperoleh salah satunya dengan pengamatan langsung di lapangan yaitu selama penulis praktek di MV. Oriental Ruby. Data ini bersumber dari hasil observasi langsung terhadap kegiatan operasional kapal pada saat pelaksanaan pelashingan. Dapat disimpulkan bahwa data primer adalah data yang bersumber dari narasumber asli yang salah satu metodenya adalah dengan wawancara. Narasumber dalam penelitian ini adalah Mualim I,2 dan 3 . Mualim I,2 dan 3 sebagai narasumber karena mereka merupakan perwira yang berada dilapangan langsung pada saat proses pelashingan.

Data Sekunder Menurut Asep Hermawan dalam bukunya Penelitian Bisnis (2005:168) "data sekunder" merupakan struktur data historis mengenai variable-variabel yang telah dikumpulkan dan dihimpun sebelumnya oleh pihak lain. Data yang digunakan penulis bersumber dari buku-buku, literatur, jurnal, maupun referensi lainnya yang memiliki keterkaitan dengan penulisan ini, sehingga dapat memberikan gambaran secara utuh, lengkap, 
dan menyeluruh. Data sekunder ini digunakan penulis sebagai pendukung data primer dan untuk tinjauan pustaka. Penulis memperoleh data-data sekunder tersebut dari dokumen-dokumen di atas kapal MV. Oriental Ruby dan referensi buku-buku serta jurnal yang ada di perpustakaan PIP Semarang dan $e$-books yang berhubungan dengan pelashingan muatan kontainer yang dapat dijadikan sebagai penunjang. Metode pengumpulan data merupakan satu bagian penting dan harus ada dalam penelitian ilmiah. Informasi dan data serta keterangan yang lengkap, bersifat informatif dan objektif, serta dapat dipertanggung jawabkan sangat diperlukan agar dapat dijadikan bahan dasar serta menjadi acuan dalam penyusunan sebuah skripsi. Dalam pelaksanaannya seorang peneliti harus menggunakan metode tertentu untuk mengumpulkan data yang tersusun secara sistematis sesuai dengan tujuan penelitian. Ada beberapa macam teknik atau metode yang dipergunakan untuk mengumpulkan data. Di dalam penelitian ini penulis menggunakan beberapa teknik pengumpulan data yang penulis anggap paling tepat, yaitu: Metode Observasi, Metode Dokumentasi, Metode Kepustakaan. Metode yang digunakan untuk menganalisa data dalam skripsi ini menggunakan metode kualitatif, dimana dalam skripsi ini terdapat pemaparan semua kejadian atau peristiwa yang terjadi dikapal yang berhubungan dengan permasalahan yang dibahas dalam skripsi ini. Pengamatan dan pandangan terhadap data yang ada mulai dari pokok permasalahan yang terjadi, membaca kumpulan data, dikaji berdasarkan teori-teori yang dapat memberikan pemecahan masalah yang terbaik sehingga permasalahan yang timbul dapat diatasi dengan solusi..

Metode Fishbone Analysis adalah salah satu metode analisa data yang digunakan untuk meningkatkan kualitas dalam mengidentifikasi suatu penyebab permasalahan. Fishbone Analysis sering juga disebut dengan diagram sebab akibat atau cause effect. Dikatakan Fishbone Diagram, karena memang berbentuk mirip dengan tulang ikan yang moncong kepalanya menghadap kekanan. Diagram ini akan menunjukkan sebuah dampak atau akibat, dari sebuah permasalahan dengan berbagai penyebabnya.

Metode fishbone digunakan penulis untuk melakukan identifikasi masalah yang sebenarnya atau yang sedang dialami. Masalah utama yang terjadi, kemudian digambarkan dengan bentuk segitiga sebagai kepala ikan dari fishbone analysis. Masalah yang diidentifikasi akan menjadi pusat perhatian dalam proses pembuatan fishbone analysis. Dari masalah yang ada, maka ditentukan faktor-faktor utama yang menjadi penyebab dari permasalahan tersebut. Faktor-faktor ini akan menjadi penyusun tulang utama dari fishbone analysis. Faktor ini dapat berupa sumber daya manusia, metode yang digunakan, cara produksi, dan lain sebagainya,. Penulis mempunyai faktorfaktor utama yang menjadi permasalahan yaitu manusia, alam, prosedur, dan peralatan.

\section{DISKUSI}

\section{A. Analisis Masalah}

Sesuai dengan prosedurnya, seluruh kegiatan di atas kapal memiliki perencanaan, sebelum container dimuat atau dibongkar di atas kapal pertama. Berdasarkan penelitian, dan perhitungan dari Mualim I, bay plan dan lashing harus disesuaikan dengan stabilitas aman kapal dan keselamatan muatan, begitu pula dengan dokumennya harus lengkap dan telah di segel oleh pejabat kepabeanan. Nakhoda sebagai orang terakhir yang menyetujui perencanaan setiap pengoperasian menyesuaikan dengan data yang di kirim oleh perusahaan memastikan tidak ada yang terlewatkan ataupun hilang yang dapat mengganggu proses bongkar muat bahkan merugikan perusahaan. Setelah semua persyaratan disetujui oleh Nahkoda, barulah proses bongkar muat di kapal dilaksanakan. Setelah itu Mualim I memberi salinan bay plan dan lashing plan kepada para perwira. Sesuai jam jaganya, para mualim jaga mengawasi setiap proses bongkar muat dan pelashingannya. Kegiatan tersebut dicatat dalam buku yang disebut port log book. Buku ini nantinya berguna sebagai bukti dari laporan setiap kegiatan bongkar muat di pelabuhan, dimana terdapat keterangan waktu dari setiap proses bongkar muat dan proses lashing. Berdasarkan peraturan yang berlaku di setiap kapal yang disesuaikan dengan jumlah crew di atas kapal, dalam mengawasi pengoperasian muatan perwira jaga di bantu oleh 1 orang Jurumudi dan 1 orang Cadet dengan waktu jaga yang telah disesuaikan oleh Mualim I serta berpedoman pada aturan yang telah di atur oleh ILO (International Labour Organitation). Pada intinya dalam pemuatan di atas kapal menyangkut beberapa aspek, antara lain prinsip memuat dan cara pemuatan. Sesuai dengan fakta yang ada, salah satu dari beberapa sumber- 
sumber kerusakan terhadap muatan dalam container terjadi pada saat pelayaran. Dengan ikatan yang kurang baik, maka sangat membahayakan kapal, muatan, terlebih kepada manusia. Hal ini sering dialami saat kapal mengalami olengan sehingga container yang tidak terikat dan terletak pada susunan atas pada tier terakhir mengalami pergerakan-pergerakan yang bisa membahayakan. Oleh karena itu, untuk menghindari hal-hal yang tidak diinginkan terhadap muatan container pada saat pelayaran, maka perlu adanya pengamanan dalam pelashingan container yang sesuai petunjuk dan cara pelashingan di dalam Lashing Securing Stowage \& Condition Survey tentang pengamanan container. Lashing Securing Stowage \& Condition Survey berarti sebuah inspection atau pemeriksaan dan pengawasan pengamanan atas "pelashingan" cargo / barang muatan di atas kapal. kegiatan Lashing Securing Stowage \& Condition Survey adalah suatu kegiatan yang dilakukan untuk mengecek keamanan pelashingan. karena walaupun dengan adanya pengaturan penempatan muatan atau stowage plan, lashing securing juga perlu diperhatikan agar muatan betul-betul aman untuk proses transport.

Oleh karena itu, berdasarkan hasil pengamatan langsung dari lapangan, selama melaksanakan masa praktek laut, penulis sebagai seorang Cadet diatas kapal berhasil mengumpulkan data-data dari permasalahan yang ditemukan selama penelitian, antara lain:

\section{Kasus pertama selama on board}

Permasalahan pertama yang ditemukan oleh penulis yaitu pada saat pembongkaran muatan dimana setelah alat-alat lashing di lepaskan dari container, peralatan tersebut seringkali tidak di tempatkan pada tempatnya dan di biarkan berserakan. Contohnya pada twistlock yang seringkali ditemukan berserakan pada daerahdaerah yang rawan. Hal ini dapat menimbulkan kerugian dan bahaya karena dapat mengakibatkan twistlock jatuh ke laut bahkan dapat menimpa seseorang yang sedang berjalan pada saat kapal mengalami rolling atau gerakan lainnya dalam pelayaran. Sementara pada lashing bar dan turnbuckle yang berserakan di atas palka kemudian tertimpa oleh muatan yang dimuat on deck akan mengalami lengkungan. Kurangnya pemahaman tersebut dapat mengurangi jumlah persediaan peralatan lashing di atas kapal dan mempengaruhi kualitas ikatan di atas kapal. Perlu di ketahui bahwa kondisi fisik alat lashing juga mempengaruhi proses dan hasil pelashingan. Jika turnbuckle melengkung maka akan mengakibatkan kesulitan pengencangan lashing selain itu juga dapat mempengaruhi waktu dan tenaga yang di gunakan saat melakukan pelashingan. Saat turnbuckle/lashing bar melengkung maka pada saat kita akan melaksanakan pelashingan muatan, pastinya kita membutuhkan tenaga yang lebih untuk mengencangkan.

2. Kasus kedua perjalanan Makassar ke Nabire Pada hari Minggu tanggal 08 Juli 2018 di laut Banda dengan kondisi laut moderate sea pada pukul 13.15LT saat jam jaga Mualim 2, satu orang Jurumudi dan saya sebagai Cadet. Pada saat itu MV. Oriental Ruby yang dalam pelayarannya dari Makassar ke Nabire, peti kemas mengalami olengan ke kiri-kanan muatan on deck di bay 37-39, melihat itu saya melaporkan ke Mualim jaga yang saat itu adalah Second Officer. Lalu perwira jaga menghubungi Boatswain, segera saya dan Boatswain turun untuk mengecek kondisi lashing dan setelah dicek ternyata hal tersebut dikarenakan oleh kurangnya lashing sehingga saya dan Boatswain menambah lashing ke muatan agar peti kemas tidak mengalami olengan dan tidak jatuh. Inilah salah satu bukti pentingnya menerapkan prosedur lashing diatas kapal.

B. Pembahasan Masalah

Penulis mencoba menguraikan bagaimana cara lashing container yang baik serta solusi untuk menanggulangi kendala-kendala yang timbul pada saat lashing container lainnya. Metode fishbone analysis adalah salah satu metode analisis data yang digunakan untuk meningkatkan kualitas dalam mengidentifikasi suatu penyebab permasalahan. fishbone analysis sering juga disebut dengan diagram sebab akibat atau cause effect. Dikatakan fishbone analysis, karena memang berbentuk mirip dengan tulang ikan yang moncong kepalanya menghadap kekanan. Pendekatan fishbone analysis yang digunakan untuk menjabarkan faktor-faktor penyebab pergeseran muatan container on deck, sebagai berikut:
1. Alam
2. Prosedur
3. Peralatan
4. Manusia 
Teknik Pelashingan Muatan Kontainer On Deck Pada Kapal MV.Oriental Ruby Untuk Penanggulangan

Pergeseran Muatan

Aziz, $S^{\text {a }}$, Andromeda, V.F

Tabel Faktor Permasalahan Fishbone

\begin{tabular}{|l|l|}
\hline \multicolumn{1}{|c|}{ Faktor yand diamati } & \multicolumn{1}{|c|}{ Masalah yang terjadi } \\
\hline 1.Alam & $\begin{array}{l}\text { Ombak tinggi yang } \\
\text { menghantam lambung } \\
\text { kapal }\end{array}$ \\
\hline 2.Prosedur & $\begin{array}{l}\text { Kurangnya pemahaman } \\
\text { pemakaian alat lashing } \\
\text { kontainer yang sesuai } \\
\text { kegunaannya }\end{array}$ \\
\hline 3.Peralatan & Terbatasnya alat lashing \\
\hline 4.Manusia & $\begin{array}{l}\text { Kurangnya pemeriksaan } \\
\text { dan perawatan alat lashing } \\
\text { dan pengawasan terhadap } \\
\text { proses lashing kontainer } \\
\text { oleh Perwira. }\end{array}$ \\
\hline
\end{tabular}

Jadi secara umum metode fishbone adalah sebuah metode menyelesaikan kasus apabila terjadi sesuatu kegagalan atau hal yang tidak diinginkan dengan mencari akar-akar permasalahan yang muncul dan diuraikan dari setiap indikasi kejadian puncak.

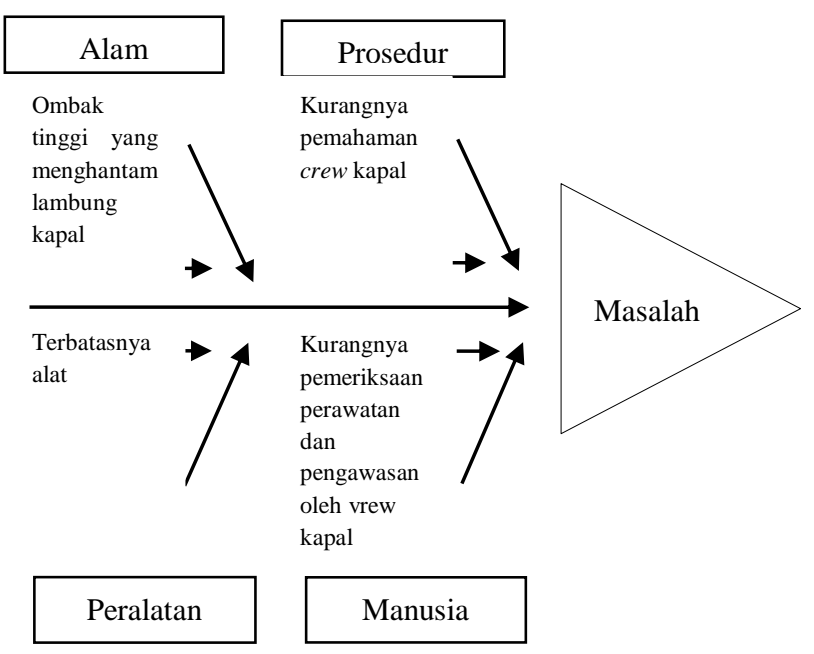

Gambar Diagram Fishbone Analysis

1. Faktor Alam

Faktor alam dalam hal ini yang adalah ombak yang tinggi. Ombak adalah pergerakan naik turunnya air dengan arah tegak lurus permukaan air laut, yang membentuk kurva atau grafik sinusoidal. Gelombang laut biasanya disebabkan oleh angin. Angin di atas lautan memindahkan tenaganya ke permukaan perairan, yang menyebabkan riak-riak, alunan atau bukit, dan berubah menjadi apa yang disebut ombak. Dengan keadaan seperti itu, pada saat ombak yang tinggi menghantam kapal dapat mengakibatkan kapal oleng ke kiri-kanan. Keadaan lashing yang tidak sesuai dengan prosedur yang ada akan menyebabkan muatan on deck mengalami olengan ke kiri-kanan sesuai dengan keadaan kapal. Jika itu terus terjadi muatan akan bisa bergeser dan bahkan bisa jatuh di deck yang menyebabkan muatan didalamnya rusak dan bahkan muatan kontainer tersebut jatuh ke laut. Mualim jaga harus selalu waspada apabila terjadi cuaca buruk saat kapal sedang berlayar. Maka dari itu, ombak merupakan faktor yang menyebabkan pergeseran muatan on deck saat MV. Oriental Ruby berlayar di laut dengan ombak yang tinggi.

\section{Faktor Prosedur}

Pengawasan dari perwira terhadap crew kapal yang melaksanakan pembongkaran / pelashingan peti kemas kurang di optimalisasi, maka crew kapal akan melakukan pelashingan container sesuai dengan keinginan dan kemampuannya saja. Sehingga jika terdapat pelashingan yang tidak sesuai maka perlu dilaksanakan perbaikan terhadap pelashingan tersebut sesuai dengan prosedur lashing yang benar. Contohnya pada pemasangan twistlock atau pemasangan bridge fitting. Pada saat penulis melaksanakan praktek laut diatas kapal MV. Oriental Ruby, penulis mengamati proses pelashingan container diatas kapal MV. Oriental Ruby sering tidak sesuai dengan sistem prosedur tentang pelashingan muatan container diatas kapal dimana pada tier teratas on deck tidak terikat dengan baik, misalnya pemasangan lashing bar, dan twislock / stacking cone, serta pemasangan bridge fitting.

\section{Faktor Peralatan}

Cadangan alat lashing container dikapal sangatlah perlu karena jika kapal memuat muatan peti kemas dalam jumlah teus yang maksimal maka pengggunaan alat lashing yang dibutuhkan akan berubah sebab jika alat lashing kurang maka akan terdapat beberapa muatan yang tidak dapat terikat. Oleh karena itu, pihak kapal dalam hal ini Mualim 1 sebagai perwira muatan perlu mengadakan pemeriksaan secara rutin, jika terdapat kekurangan terhadap peralatan lashing maka segera mengirim permintaan. Selain itu, jika permintaan alat lashing dari perusahaan mengalami keterlambatan, maka alat lashing container yang ada diatas kapal dapat dimanfaatkan atau digunakan sebagai alat lashing container sudah 
sampai dikapal dapat difungsikan sebagai cadangan atau spare. Dengan cara demikian maka masalah kekurangan alat lashing container tidak akan terjadi lagi.

4. Faktor Manusia

Untuk menjaga kualitas serta kelayakannya, maka perawatan peralatan lashing container sangatlah penting, karena dengan perawatan yang baik dan terkontrol maka akan menambah umur pemakainya alat lashing tersebut. Pengawasan terhadap crew kapal yang melaksanakan pelashingan container sangatlah penting. Sebab dengan pelashingan yang baik, keselamatan muatan yang di muat dapat di jamin sampai ke pelabuhan tujuan. Di dalam proses pelashingan container biasanya crew kapal, tidak teliti dalam proses pelashingan container. Pelashingan container yang tidak sesuai prosedur ini dapat diketahui dengan pengamatan secara langsung pada container yang telah dimuat dan dalam proses pelashingan.

Secara keseluruhan upaya-upaya yang dapat dilakukan dalam tahapan pemecahan masalah yang telah dijelaskan dalam bab sebelumnya. Upaya-upaya ini nantinya dapat diterapkan pada penyebab utama timbulnya masalah yaitu pergeseran muatan on deck di kapal MV.Oriental Ruby. Oleh karena itu untuk memperoleh pemecahan masalah yang sesuai dengan pokok permasalahan yang dibahas, maka upaya-upaya tersebut akan dievaluasi kembali sehingga nantinya diharapkan dapat ditemukan suatu solusi yang tepat dan akurat. Berdasarkan dari alternatif pemecahan masalah yang ditemukan oleh penulis maka evaluasievaluasi yang dilakukan untuk menanggulangi permasalahan tersebut antara lain :

1. Pelaksanaan safety meeting di kapal.

Kegiatan safety meeting yang diadakan di atas kapal setiap 1 bulan sekali, selain bertujuan untuk membahas hasil-hasil yang telah dicapai dalam sebulan kerja oleh seluruh crew kapal dan juga yang membahas tentang pokok-pokok keselamatan di atas kapal dapat dijadikan pula sebagai suatu sarana dalam melakukan kegiatan familiarisasi terhadap crew kapal yang ada di atas kapal. Kegiatan ini dapat dilaksanakan setelah seluruh topik tentang keselamatan di atas kapal yang mana merupakan inti pokok dari dilaksanakannya safety meeting di atas kapal dibahas, sehingga crew kapal dapat berkonsentrasi penuh pada materi-materi yang diberikan dan hasil yang diperoleh dari kegiatan ini dapat tercapai dengan maksimal yaitu crew kapal sadar akan pentingnya pengecekan lashing muatan dalam mendukung tercapainya fungsi dan manfaat pelashingan muatan, sehingga keselamatan muatan, kapal dan crew kapal dapat terjamin. Agar pelaksanaannya dapat berjalan dengan efisien maka ada baiknya jika Mualim 1 yang merupakan Perwira muatan di atas kapal dan juga sebagai perwira senior di atas kapal yang menjadi pembicara atau yang menjelaskannya secara langsung. Hal tersebut dikarenakan Mualim 1 secara umum lebih mengenal alat-alat dan fasilitas-fasilitas tertentu yang diperlukan dalam penanganan muatan.

2. Pengadaan check list terhadap alat pengamanan muatan.

Pengadaan check list pengamanan muatan di atas kapal bermanfaat dalam menunjang efektifitas kegiatan pelashingan yang akan dilakukan crew kapal, khususnya bagi crew kapal yang berdinas jaga yang dalam hal ini adalah Perwira jaga dan ABK jaga yang mana memiliki tanggung jawab yang besar dalam menunjang keselamatan muatan, kapal dan crew kapal juga efisiensi pengoperasian kapal di pelabuhan. Check list yang dibuat harus berdasarkan bentuk dan type kapal selain itu pelaksanaannya harus dilakukan secara periodik agar tidak ada satupun pelashingan muatan yang tidak teramati dengan baik sehingga muatan yang dimuat dapat terjamin keamanannya. Perlu disadari bahwa dengan tidak adanya pedoman bagi crew kapal dalam hal pengecekan dan pengawasan menyebabkan crew kapal cenderung berbuat salah, pengecekan ini dilaksanakan oleh Perwira jaga yang berdinas jaga pada saat itu, saat muatan seluruhnya telah selesai di muat di atas kapal.

3. Prosedur standar lashing container di on deck yang sesuai.

Setelah diadakan safety meeting tentang manfaat dan fungsi daripada pemasangan lashing diatas kapal dan teknik-teknik pemasangan lashing yang benar sesuai prosedur yang ada di atas kapal, dan memberlakukan sanksi yang tegas oleh Nakhoda serta melakukan checklist terhadap alat-alat pengamanan muatan, maka crew kapal diharapkan dapat melaksanakan dengan sesuai prosedur lashing container secara efisien untuk mengurangi, mencegah bahkan meniadakan pergeseran muatan di on deck kapal MV. Oriental Ruby. 
4. Pengecekan terhadap alat-alat lashing yang sudah terikat ke muatan ketika kapal berlayar.

Ini perlu diperhatikan ketika kapal berlayar terutama saat cuaca buruk, karena alat-alat lashing bisa saja kendor dan memastikan kembali bahwa alat-alat lashing sudah terikat dan tidak ada yang terlewatkan, sehingga menyebabkan muatan on deck mengalami pergeseran bahkan jatuh karena kapal mengalami olengan. Pengecekan bisa dilakukan oleh Perwira, Jurumudi dan Cadet atas perintah Nakhoda maupun Mualim 1 jika dirasa perlu diadakan pengecekan kembali terhadap alat-alat yang sudah terikat ke muatan.

5. Pemberian sanksi yang tegas bagi Perwira jaga dan ABK jaga yang tidak melaksanakan tuga jaga dengan baik dan benar terutama dalam melaksanakan pelashingan oleh Nakhoda.

Sebagaimana kita ketahui bahwa Nakhoda di atas kapal memegang kendali penuh terhadap kapal, crew kapal dan seluruh instrumentinstrument yang termasuk didalamnya. Hal ini dikarenakan Nakhoda adalah pemimpin kapal dan juga sebagai wakil perusahaan pelayaran atau pengusaha kapal. Oleh sebab itu keputusan atau tindakan yang diambil olehnya adalah sah dan tidak dapat diganggu gugat oleh siapapun, termasuk dalam hal penegakan disiplin yang berupa pemberian sanksi yang tegas terhadap crew kapal yang telah gagal dalam menjalankan standar-standar yang ingin dicapai terutama saat melaksanakan pelashingan muatan diatas kapal. Pemberian sanksi yang tegas dapat mendorong crew kapal sehingga ia mau bekerja atau justru melebihi ketentuan dengan baik, melaksanakan perintah dan produktif. Sanksi tegas yang harus diberikan kepada crew kapal yang berdisiplin rendah atau yang tidak dapat melaksanakan standar-standar yang ingin dicapai adalah pemecatan atau penurunan dari kapal. Perlu disadari bahwa crew kapal yang tidak dapat menjalankan standar-standar yang ingin dicapai, sudah pasti akan lebih sering melakukan kesalahan. Untuk itu agar tidak terjadi kesalahan yang lebih fatal maka alternatif ini harus dijalankan.

Pada kapal MV. Oriental Ruby, cell guide (Lashing Bridge) hanya tersedia pada bay 43/45, namun tidak tersedia pada bay 1 sampai bay 39 . Pada bagian atas dari setiap pontoon / penutup palka sudah terdapat base cone atau sepatu kontainer sebagai tempat bertumpu kontainer pada susunan pertama kemudian dipasang locking pin atau deck pin yang biasanya sudah tersedia pada setiap base cone. Setelah susunan atau tier pertama kontainer selesai maka diatasnya disiapkan untuk susunan kedua, yaitu dengan pemasangan double stacking cone pada lubang kontainer sisi luar dan pemasangan double bridge cone vertical pada lubang-lubang sisi dalam hingga kontainer-kontainer yang berdampingan diikat menjadi satu dan demikian seterusnya hingga tingkat dasar itu menjadi satu kesatuan. Kemudian disusun tier kedua hingga selesai. Kemudian dipasang lashing rod secara menyilang yang dikaitkan pada lubang dasar bagian muka dan belakang dari kontainer di tier kedua lalu dikencangkan kegeladak menggunakan turnbuckle. Untuk pemuatan pada tier ketiga akan dilakukan dengan cara yang sama namun untuk lubang-lubang kontainer atau corner casting bagian luar dipasang twistlock dimana setelah kontainer tersusun maka twistlock tersebut dikunci sehingga susunan kontainer tier kedua dan tier ketiga terikat menjadi satu. Setelah susunan ketiga selesai maka pada lubang-lubang dasar dari kontainer tier ketiga lashing rod secara tegak.

\section{KESIMPULAN}

Berdasarkan hasil penelitian yang penulis lakukan di atas kapal serta hasil pembahasan dan dari keseluruhan uraian-uraian yang terdapat dalam bab-bab sebelumnya, maka penulis mengambil beberapa kesimpulan sebagai berikut:

1. Penyebab terjadinya pergeseran muatan kontainer on deck yang bisa mengakibatkan muatan kontainer jatuh ke laut adalah:

a. Teknik pelashingan muatan kontainer on deck yang tidak baik.

b. Kurangnya pemahaman crew tentang teknik pelashingan.

2. Penyebab terjadinya pergeseran muatan kontainer on deck yang mengakibatkan kontainer rusak adalah:

a. Kurangnya pengawasan dari ABK.

b. Peralatan lashing yang kurang dan rusak.

Adapun saran dari penelitian untuk dapat meminimalisir kurangnya optimalisasi lashing serta untuk menanggulangi pergeseran muatan kontainer ialah sebagai berikut:

1. Agar muatan kontainer on deck tidak bergeser yang bisa mengakibatkan muatan kontainer jatuh ke laut dapat melakukan cara yaitu: 
a. Melakukan lashing muatan kontainer on deck sesuai prosedur dan teknik yang benar.

b. Pemberian pemahaman oleh Mualim 1 tentang penanganan muatan pada saat safety meeting di atas kapal.

2. Agar muatan kontainer on deck tidak bergeser yang bisa mengakibatkan kontainer rusak dapat melakukan cara yaitu:

a. ABK jaga yang dipimpin oleh Perwira jaga melakukan pengecekan kembali terhadap kontainer on deck dan alat-alat lashing yang sudah terikat sebelum dan sesudah kapal berlayar.

b. Pengadaan checklist alat-alat pengamanan muatan agar bisa dilakukan permintaan dan perawatan alat-alat lashing.

\section{DAFTAR PUSTAKA}

Abrori, Mokhammad. 2017. Jurnal Saintek Maritime Volume XVI Nomor 2.

Fakhurrozi. 2017. Muatan Kapal. Jogjakarta: Deepublish

Gulo .W. 2000. Metodologi Penelitian. Jakarta: Grasindo

Hermawan, Asep. 2005. Penelitian Bisnis. Jakarta: Grasindo

https://www.scribd.com/doc/94171023/ContainerShip-and-Cargo-Securing-in-Indonesian. 2012.

http://www.trotech.com/products.php?cat id=3, 2013

Martopo Arso. 2001. Penanganan Muatan. Semarang.

Siddik, Mohammad. 2016. Dasar-Dasar Menulis Dengan Penerapannya. Malang: Tunggal Mandiri Publishing

Soewedo, Hananto. 2015. Penanganan Muatan Kapal. Jakarta: Maritime Djangkar

Suwendra, I, Wayan. 2018. Metodologi Penelitian Kualitatif. Bali: Nilacakra

Tim Pandom. 2014 .KBBI (Kamus Besar Bahasa Indonesia) 